\title{
Realistic Mathematics Education in Indonesia and Recommendations for Future Implementation: A Meta-Analysis Study
}

\author{
Maximus Tamur ${ }^{1}$, Dadang Juandi ${ }^{2}$, Angela Merici G. Adem ${ }^{3}$ \\ ${ }_{1}^{1}$ Indonesia Santu Paulus Ruteng Indonesian Catholic University, Ruteng, Indonesia \\ ${ }^{2}$ Department of Mathematics, Indonesian University of Education, Bandung, Indonesia \\ 3Teachers College Columbia University, United States of America \\ 1maximustamur@unikastpaulus.ac.id, 리adangj.juandi@upi.edu, ${ }^{3}$ aga2146@tc.columbia.edu
}

\begin{abstract}
\begin{tabular}{l}
\hline \hline \\
\hline Article History: \\
Received : 07-02-2020 \\
Revised : 22-03-2020 \\
Accepted : 25-03-2020 \\
Online : 02-04-2020 \\
\hline
\end{tabular}
Keyword:

Realistic Mathematics Education;

Meta-analysis;

Mathematical Ability.

\section{ABSTRACT}

This meta-analysis study aims to investigate the effectiveness of applying realistic mathematics education (RME) in Indonesia to students' mathematical abilities. This study analyzes 95 effect sizes from 72 studies that have been published in national and international journals or proceedings from 2010 to 2019. Comprehensive Meta-Analysis (CMA) software is used to aid analysis. As a result of the study, the overall effect size was 1.104, with a standard error of 0.065 according to the random-effects model. These results indicate that the average person who is ranked 13th in the experimental group is equivalent to those who are ranked 4th in the control group. This research was carried out by considering four characteristics, resulting in significant differences in terms of sample size and duration of treatment. Thus the application of RME in Indonesia is very effective in improving students' mathematical abilities by considering the sample size and duration of treatment.
\end{abstract}

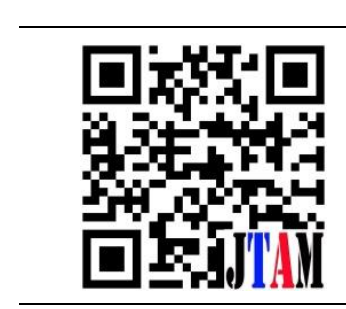

doi) Crossref

https://doi.org/10.31764/jtam.v4i1.1786

\section{A. INTRODUCTION}

Realistic Mathematics Education (RME) is a teaching theory specifically for the mathematics domain, which has been developed in the Netherlands (Panhuizen \& Drijvers, 2014). Since its discovery in the 1960s to the present, the RME has influenced the international curriculum and mathematical pedagogy (Clements, Keitel, Bishop, Kilpatrick, \& Leung, 2013). RME helps teachers to teach mathematics to students and successfully improve their mathematical abilities (Ekowati \& Nenohai, 2016; Fauzan, Slettenhaar, \& Plomp, 2002; Hasibuan, Saragih, \& Amry, 2019; Turmudi, 2012; \& Zulkardi, 2002). This recommendation triggers educational researchers to replicate research on the application of RME.

Various studies have found the application of RME in Indonesia affects the mathematical abilities of students (Hasratuddin, 2010; Putri, 2011; Artawa, Wyn, \& Suwatra, 2012; Palinussa, 2013; Rohmah, Caswita, \& Widyastuti, 2014; Rohman \& Sugiman, 2015; Yunisha, 
Prahmana, \& Sukmawati, 2016; Nursiddik, Noto, \& Hartono, 2017; Dwi Yanti, Wahyu Widada, \& Zamzaili, 2018; Husniyah, Sulistiani, \& Mustafida, 2019). However, to date in the literature, no comprehensive evaluation has been carried out on the effect of RME on students' mathematical abilities. In addition, the researchers have not investigated further the effects of study characteristics such as study years, sample size and education levels, and the duration of the experiment as moderator variables, which might also explain the effect of RME on students' mathematical abilities. On the other hand, the government and related parties need a comprehensive conclusion about the effectiveness of the RME, along with the characteristics that influence its implementation in the future.

Investigating the effect of RME on mathematical ability in terms of the characteristics of the study cannot be done with primary studies. Meta-analysis is seen as an objective method of literature review because it uses effect sizes. This procedure ignores subjective interpretations of various research reviews on the same topic or method (Borenstein \& Hedges, 2009; Cohen, 1988). Meta-analysis is to collect the results of studies consistently and precisely (Hedges \& Olkin, 1985; Cohen, 1988). Meta-analysis is a quantitative technique that uses specific steps (for example, effect sizes) to show the strength of the variable relationships for the studies included in the analysis (Cleophas \& Zwinderman, 2017; Schwarzer, Carpenter, \& Rücker, 2015; Shelby \& Vaske, 2008).

Several Meta-analysis studies conducted by (Asror, 2016, Prasetiyo, Yusmin, \& Hartoyo, 2014; Shelby \& Vaske, 2008; Turgut \& Turgut, 2018) are analyzing the effectiveness of the effects of learning interventions such as the effect of Problem Based Learning and cooperative models and the use of media on students' mathematical thinking abilities. There is no specific meta-analysis about RME. As a result, an in-depth and comprehensive picture of how the RME effect is seen from various study characteristics such as sample size, the year when the study was conducted, school level, etc. have not been examined. This explanation shows that a comprehensive meta-analysis of the effectiveness of RME on students' mathematical abilities is needed to evaluate its application and see the overall trends clearly. This underlies researchers to investigate the effect of the application of RME on students' mathematical abilities with the help of meta-analysis methods. In this context, this study examines the following questions:

1. Does the application of RME produce a greater effect size on students' mathematical abilities than conventional approaches?

2. Does the effect size of students' mathematical abilities from applying RME between different study groups reviewed from the study year?

3. Does the effect size of students' mathematical abilities from applying RME between different study groups in terms of education level?

4. Does the effect size of students' mathematical abilities from applying RME between different study groups in terms of sample size?

5. Does the effect size of students' mathematical abilities from applying RME between different study groups in terms of the duration of the experiment?

\section{B. METHODS}

\section{Research Design}

This study aims to statistically evaluate the findings of primary studies examining the effect of the application of RME on the mathematical abilities of students in Indonesia, using a meta-analysis method. Meta-analysis provides an overall evaluation with statistical analysis of quantitative data obtained in independent studies on specific subjects (Cleophas \& Zwinderman, 2017; GLASS, 1976; \& Schwarzer et al., 2015). Effect size is a simple way to measure differences between two groups, which have many advantages compared to using statistical significance tests alone (Coe, 2002; Ellis, 2010; Thalheimer \& Cook, 2002). Meta- 
analysis is carried out by following the steps; First, the criteria for the study included in the meta-analysis will be presented. Second, the procedure for finding studies and coding of study variables will be explained. Third, statistical techniques to investigate the relationship between study variables and effect sizes (Borenstein, Hedges, \& Rothstein, 2007; Pigott, 2012). This stage was also carried out in this study.

\section{Inclusion Criteria}

The studies included in this analysis were selected from experimental and quasiexperimental studies comparing the achievement of studies taught with RME and students taught with conventional approaches. Studies included in limited synthesis were conducted in Indonesia in the past decade (2010-2019). The statistics needed for this transformation are the mean, standard deviation, and sample size. In addition, the information needed to investigate the research question is the source of the publication, the year of study, and the duration of the treatment.

\section{Study Search}

The study included in the analysis was found using an electronic database, the Education Resource Information Center (ERIC), and a journal published by Springer. The keywords used are "Realistic Mathematics Education." Furthermore, to reach journal articles and national seminar proceedings in Indonesia, we use the Google Scholar search engine. The keyword used is "Pendidikan Matematika Realistik." Table 1 shows information about studies that have been published by various journals.

Table 1. List of journals that publish studies on RME

\begin{tabular}{|c|c|c|c|}
\hline No & Journal Name & URL & Country \\
\hline 1 & Journals indexed by ERIC & https://eric.ed.gov/?Journals & $\begin{array}{l}\text { Indonesian } \\
\text { Author }\end{array}$ \\
\hline 2 & $\begin{array}{l}\text { Journals published by } \\
\text { Springer }\end{array}$ & https://link.springer.com & $\begin{array}{l}\text { Indonesian } \\
\text { Author }\end{array}$ \\
\hline 3 & $\begin{array}{l}\text { Journals indexed by Google } \\
\text { Scholars }\end{array}$ & https://scholar.google.com/scholar & Indonesia \\
\hline 4 & Mosharafa & $\begin{array}{l}\text { https://journal.institutpendidikan.ac.id/index.php } \\
\text { /mosharafa }\end{array}$ & Indonesia \\
\hline 5 & Prosiding Seminar Nasional & $\begin{array}{l}\text { http://ejournal.radenintan.ac.id/index.php/pspm } \\
\text { /index }\end{array}$ & Indonesia \\
\hline 6 & Riset Pendidikan Matematika & https://journal.uny.ac.id/index.php/jrpm & Indonesia \\
\hline 7 & EJournal Undiksha & https://ejournal.undiksha.ac.id/ & Indonesia \\
\hline 8 & $\begin{array}{ll}\text { Penelitian } & \text { Pendidikan } \\
\text { Matematika } & \\
\end{array}$ & http://jurnal.um-palembang.ac.id/jpm & Indonesia \\
\hline 9 & Kadikma & https://jurnal.unej.ac.id/index.php/kadikma & Indonesia \\
\hline 10 & Teori dan Aplikasi Matematika & http://journal.ummat.ac.id/index.php/jtam/index & Indonesia \\
\hline 11 & Jurnal Gantang & https://ojs.umrah.ac.id/index.php/gantang & Indonesia \\
\hline 12 & $\begin{array}{l}\text { Pembelajaran } \\
\text { Matematika }\end{array}$ & http://ojs.uho.ac.id/index.php/JPBM & Indonesia \\
\hline & Muallimuna & $\begin{array}{l}\text { https://ojs.uniska- } \\
\text { bjm.ac.id/index.php/jurnalmuallimuna }\end{array}$ & Indonesia \\
\hline & Edukasi Matematika dan Sains & http://e-journal.unipma.ac.id/index.php/JEMS & Indonesia \\
\hline & Raflesia & https://ejournal.unib.ac.id/index.php/jpmr & Indonesia \\
\hline & Cakrawala Pendidikan & https://journal.uny.ac.id/index.php/cp & Indonesia \\
\hline & Edumatica & https://online-journal.unja.ac.id/edumatica & Indonesia \\
\hline & Pendidikan Matema & https://ejournal.unsri.ac.id/index.php/jpm/index & Indonesia \\
\hline & Buana Matematika & http://jurnal.unipasby.ac.id/index.php/buana_ma & Indonesia \\
\hline
\end{tabular}




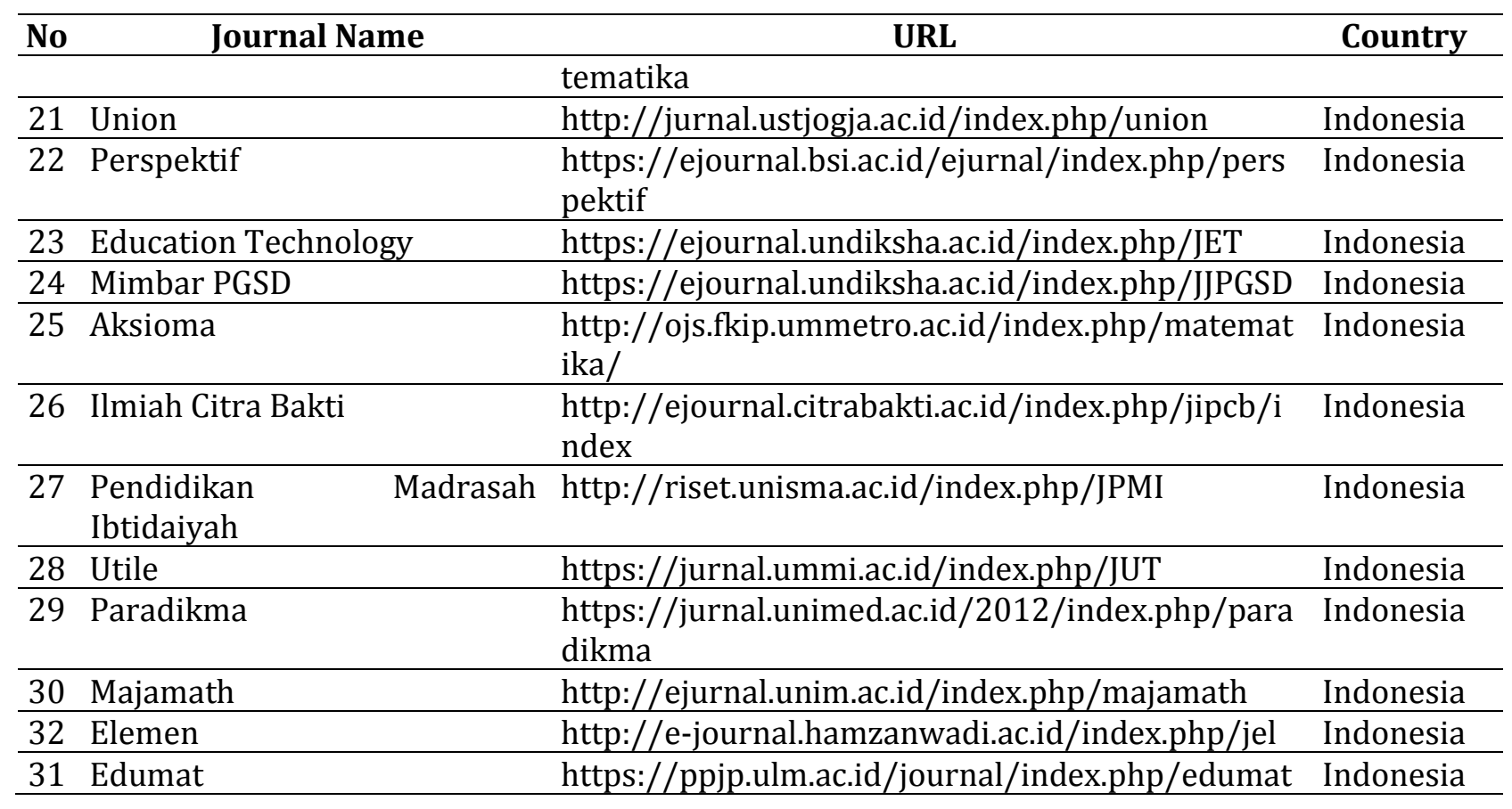

As explained in Table 1, the list of journals that published studies on RME was 31. Search results found 216 studies examining the application of RME in mathematics learning in Indonesia from 2010 to 2019. In accordance with the inclusion criteria, studies that were used in the analysis were 72 . However, because some studies tested more than one comparison, there were 95 effect sizes analyzed. In a study that did not include the duration of the treatment, the researcher cross-referenced the original author by email in the journal. Table $\mathbf{2}$ shows the information about the study.

Table 2. Information about the Study

\begin{tabular}{|c|c|c|}
\hline Study Characteristics & Group & $\mathbf{f}$ \\
\hline \multirow{2}{*}{$\begin{array}{l}\text { The year of the study } \\
\text { was conducted }\end{array}$} & $2010-2015$ & 54 \\
\hline & 2016-2019 & 41 \\
\hline \multirow[t]{3}{*}{ School Level } & Primary School (PS) & 44 \\
\hline & Junior High School (JHS) & 47 \\
\hline & Senior High School and Vocational High School (JHS \& VHS) & 4 \\
\hline \multirow[t]{2}{*}{ Sample Size } & 30 or less & 53 \\
\hline & 31 or over & 42 \\
\hline \multirow{3}{*}{$\begin{array}{l}\text { Duration of the } \\
\text { Experiment }\end{array}$} & $0-7$ hours & 38 \\
\hline & 8-14 hours & 18 \\
\hline & 15 hours or more & 39 \\
\hline
\end{tabular}

\section{Reliability Test}

The instrument in this study was carried out by coding code sheets. To ensure data is entered without error, the two encoders fill out the encoding form separately and then compare. If there is still data that is not the same, then match it again. The most important criticism that is common in meta-analysis studies is publication bias, which is the tendency of journals to publish only significant studies that lead to meta-analyzes that are too high for actual effect sizes (Borenstein \& Hedges, 2009; Park \& Hong, 2016). One approach, known as Trim and Fill, graphs the relationship between standard errors and effect sizes, with results referred to as funnel plots (Richard, Light, \& Pillemer, 1984, WILLETT, 1993). It said there was no publication bias if the study was distributed symmetrically. Figure 1 presents a funnel chart obtained in the study. 


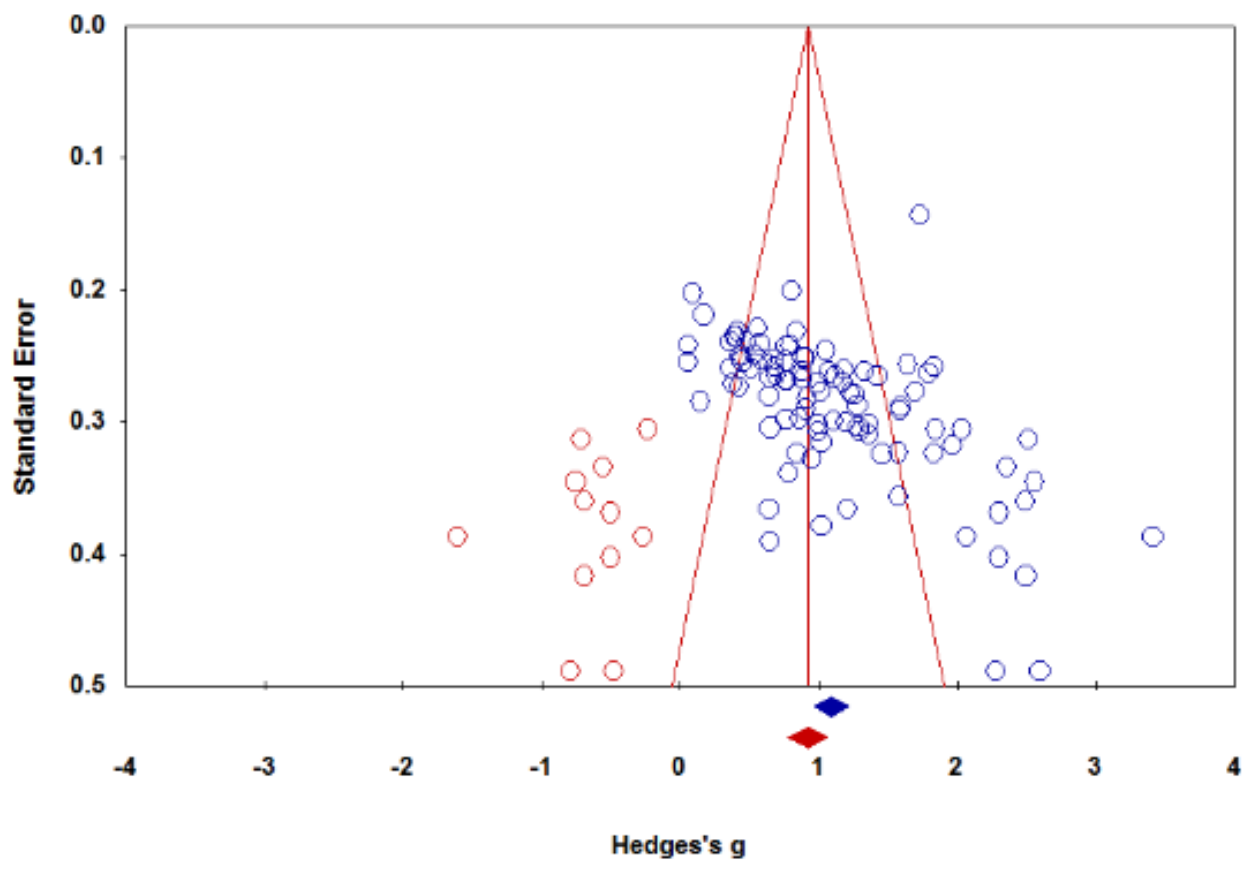

Figure 1. Funnel Chart

As explained in Figure 1, the effect size is spread almost symmetrically in the center of the funnel plot and on the left and right sides of the vertical line. Vertical lines show the size of the combined effect. Because the distribution is not fully symmetrical, Rosenthal's fail-safe N (FSN) statistics are helped to determine the probability of publication bias. From the analysis of data with the help of CMA software, the Rosenthal safe $\mathrm{N}$ value is 33411. According to the formula $\mathrm{N} /(5 \mathrm{k}+10)$ (Nursiddik et al., 2017) that is $33411 /(5 * 95+10)$, the calculation results are 68,889 . According to this calculation, it can be identified that the studies included in this analysis are resistant to publication bias. Thus it is stated that the results of the meta-analysis in this study are reliable.

\section{Statistics Analysis}

Calculation of average effect size and hypothesis testing using CMA software. The effect size used is Hedge's g. Interpretation of effect sizes, using classification (Thalheimer \& Cook, 2002) namely:

- -0.15-0.15: no level;

- 0.15-0.40: low level;

- 0.40 -0.75: moderate level;

- 0.75 -1.10: high level;

- 1.10 -1.45: very high level;

- 1.45 or higher: a very good level.

The CMA calculates the $\mathrm{Z}$ value to determine the significance test and provides an average effect size with a confidence interval for each class of variables as well as homogeneity between groups, namely the $\mathrm{Qb}$ value. As a result of the calculation, if Zcount $>\mathrm{Z}$ table with $\mathrm{p}$ $<0.05$, then the null hypothesis is rejected (Borenstein \& Hedges, 2009). This means that the application of RME produces a greater effect size on students' mathematical abilities than conventional approaches. When the effect size is statistically heterogeneous $(\mathrm{Qb}>\chi 2.95 ; \mathrm{p}$ $<0.05$ ), the hypothesis on the homogeneity of the effect size is rejected (Demir \& Başol, 2014). The random effect model is used when $\mathrm{Qb}$ is blocked. Rejecting $\mathrm{Qb}$ implies that the effect sizes of the study characteristic groups may not measure the same population parameters 
(Borenstein \& Hedges, 2009). In other words, there is a statistically significant difference in the average effect size for each group of study characteristics (Bayir \& Bozkurt, 2018).

\section{RESULT AND DISCUSSION}

The first objective of this study was to determine the overall effectiveness of learning applying RME to students' mathematical abilities. Based on the overall calculation, the effect sizes from each study are presented in Table 3, which is exported from the following CMA outputs:

Table 3. Effect Size of Each Study

\begin{tabular}{|c|c|c|c|c|c|}
\hline No & Author & Effect Size & No & Author & Effect Size \\
\hline 1 & Hasratuddin, 2010 & 1.71 & 49 & Wewe, 2015 & 0.36 \\
\hline 2 & Putri, 2011 & 0.17 & 50 & Dewi1 a, 2015 & 0.99 \\
\hline 3 & Artawa \& Suwatra, 2012 & 1.36 & 51 & Dewi1 b, 2015 & 0.88 \\
\hline 4 & Santi, et al, 2012 & 1.83 & 52 & Rismaratri \& Nuryadi, a, 2015 & 0.89 \\
\hline 5 & Pradipta, et al,, 2012 & 0.88 & 53 & Rismaratri \& Nuryadi, b, 2015 & 1.18 \\
\hline 6 & Alam a, 2012 & 0.68 & 54 & Rohman \& Sugiman, 2015 & 0.45 \\
\hline 7 & Alam b, 2012 & 0.56 & 55 & Purwati, 2016 & 0.91 \\
\hline 8 & Alam c, 2012 & 0.77 & 56 & Yunisha, et al, 2016 & 0.48 \\
\hline 9 & Haji, 2012 & 0.68 & 57 & Ariyanti, 2016 & 1.11 \\
\hline 10 & Muntiari, et al a, 2013 & 0.64 & 58 & Gumanti, et al, 2016 & 0.51 \\
\hline 11 & Muntiari, et al b, 2013 & 1.21 & 59 & Dewi, et al, 2017 & 1.17 \\
\hline 12 & Kristinayanti, et al, 2013 & 1.96 & 60 & Budiasih, et al, 2017 & 1.58 \\
\hline 13 & Wirama, et al, 2013 & 1.28 & 61 & Ariani \& Batubara a, 2017 & 1.23 \\
\hline 14 & Mariani, et al, 2013 & 0.76 & 62 & Ariani \& Batubara b, 2017 & 2.55 \\
\hline 15 & Putra, et al, 2013 & 0.86 & 63 & Nursiddik, et al, 2017 & 2.30 \\
\hline 16 & Alim \& Jalinus, 2013 & 0.65 & 64 & Noviyana \& Fitriani, 2017 & 2.30 \\
\hline 17 & Partini, et al, 2013 & 0.36 & 65 & Melati, et al, 2017 & 0.41 \\
\hline 18 & Megayana, et al, 2013 & 0.90 & 66 & Dwipayana, et al, 2017 & 1.30 \\
\hline 19 & Rahmawati, 2013 & 0.90 & 67 & Diantari, et al, 2017 & 2.07 \\
\hline 20 & Suwarniti, et al, 2013 & 0.95 & 68 & Oktaviani, et al, 2018 & 0.42 \\
\hline 21 & Syahputra a, 2013 & 2.50 & 69 & Sumandya a, 2018 & 0.40 \\
\hline 22 & Syahputra b, 2013 & 0.39 & 70 & Sumandya b, 2018 & 0.78 \\
\hline 23 & Ria, et al, 2013 & 0.06 & 71 & Sumandya c, 2018 & 2.28 \\
\hline 24 & Astuti, et al a, 2013 & 0.57 & 72 & Wardani, 2018 & 1.57 \\
\hline 25 & Astuti, et al b, 2013 & 2.35 & 73 & Meirisa, et al, 2018 & 0.76 \\
\hline 26 & Husna, et al a, 2013 & 1.63 & 74 & Veralita, et al, 2018 & 1.69 \\
\hline 27 & Husna, et al b, 2013 & 0.84 & 75 & Raharjo, et al, 2018 & 1.07 \\
\hline 28 & Palinusa a, 2013 & 1.46 & 76 & Nengsih, 2018 & 0.14 \\
\hline 29 & Palinusa b, 2013 & 0.69 & 77 & Nopriyanti, et al a, 2018 & 0.65 \\
\hline 30 & Palinusa c, 2013 & 0.80 & 78 & Nopriyanti, et al b, 2018 & 0.76 \\
\hline 31 & Putra, et al, 2014 & 1.82 & 79 & Zulkipli \& Ansori, 2018 & 0.84 \\
\hline 32 & Wahyuni, et al a, 2014 & 0.38 & 80 & Yanti, et al, 2018 & 2.03 \\
\hline 33 & Wahyuni, et al b, 2014 & 0.42 & 81 & Nurdiansyah \& Sutisna a, 2018 & 2.50 \\
\hline 34 & Adi, et al, 2014 & 0.54 & 82 & Nurdiansyah \& Sutisna b, 2018 & 1.57 \\
\hline 35 & Sutanto, et al, 2014 & 1.29 & 83 & Nurdiansyah \& Sutisna c, 2018 & 1.78 \\
\hline 36 & Santiana, et al, 2014 & 1.11 & 84 & Prafianti, 2019 & 0.44 \\
\hline 37 & Tegeh, et al, 2014 & 1.59 & 85 & Jeheman, et al, 2019 & 0.59 \\
\hline 38 & Zaini \& Marsigit a, 2014 & 3.40 & 86 & Sihotang, 2019 & 1.05 \\
\hline 39 & Zaini \& Marsigit b, 2014 & 0.76 & 87 & Luthfiani, et al a, 2019 & 1.02 \\
\hline 40 & Anasrudin, et al, 2014 & 1.00 & 88 & Luthfiani, et al b, 2019 & 0.65 \\
\hline 41 & Rohmah, et al, 2014 & 0.99 & 89 & Kusumaningsih, et al, 2019 & 0.79 \\
\hline 42 & Astiti, et al a, 2014 & 0.09 & 90 & Husniyah, et al, 2019 & 1.01 \\
\hline
\end{tabular}




\begin{tabular}{llcclc}
\hline No & \multicolumn{1}{c}{ Author } & Effect Size & No & \multicolumn{1}{c}{ Author } & Effect Size \\
\hline 43 & Astiti, et al b, 2014 & 2.49 & 91 & Badaruddin, et al, 2019 & 0.05 \\
\hline 44 & Santi, et al a, 2014 & 1.42 & 92 & Julrahmat, et al, 2019 & 0.64 \\
\hline 45 & Santi, et al b, 2014 & 1.32 & 93 & Citra, et al, 2019 & 1.37 \\
\hline 46 & Nugraha, et al, a, 2015 & 1.26 & 94 & Narayani, 2019 & 1.84 \\
\hline 47 & Nugraha, et al, b, 2015 & 1.02 & 95 & Dipayana, et al, 2019 & 1.20 \\
\cline { 1 - 2 } 48 & Nugraha, et al, c, 2015 & 2.60 & & & \\
\hline
\end{tabular}

As depicted in Table 3, the overall range of effect sizes is from 0.05 to 3.40, with a 95\% confidence limit. Referring to classification (Thalheimer \& Cook, 2002), it can be examined that twenty-five effect sizes have very good levels; fifteen effect sizes have very high levels; twenty-six sizes have a high level; nineteen effect sizes have medium levels; the other six have low levels. Only four effect sizes have no level. Table 4 shows a comparison of meta-analysis results according to the effect model.

Table 4. Comparison of meta-analysis results according to the effect model

\begin{tabular}{cccccccccc}
\hline Model & $\mathbf{n}$ & $\mathbf{Z}$ & $\mathbf{p}$ & $\mathbf{Q} \mathbf{b}$ & $\begin{array}{c}\text { I- } \\
\text { squared } \\
\mathbf{p = 0 . 0 5 )}\end{array}$ & $\begin{array}{c}\text { Effect } \\
\text { Size }\end{array}$ & $\begin{array}{c}\text { Standard } \\
\text { error }\end{array}$ & \multicolumn{2}{c}{$\begin{array}{c}\text { Lower } \\
\text { Interval }\end{array}$} \\
\hline $\begin{array}{c}\text { Fixed } \\
\text { effects }\end{array}$ & 95 & 35.670 & 0.000 & 469.515 & 79.979 & 1.020 & 0.029 & 0.964 & 1.076 \\
\hline $\begin{array}{c}\text { Random } \\
\text { effects }\end{array}$ & 95 & 17.069 & 0.000 & 143.455 & 79.979 & 1.104 & 0.065 & 0.977 & 1.230 \\
\hline
\end{tabular}

As depicted in Table 4, it appears that according to the fixed-effect model, the lower limit of the $95 \%$ confidence interval is 0.964 , and the upper limit is 1.076 . The average effect size is calculated as 1,020 . This effect size is accepted as a high-level effect. Homogeneity test results revealed that the $Q$ value was 469,515 . This value was found to be greater than 117,632 in degrees of freedom 94 in table $\chi 2$. Thus, the distribution of effect sizes was found to be heterogeneous. Because the homogeneity test results were rejected, the random-effects model was evaluated. According to the random-effects model, the $95 \%$ confidence interval has a lower limit of 0.977 and an upper limit of 1230, and the average effect size is calculated as 1,104 . This effect size is accepted as a high-level effect. As a result of the calculation of the $\mathrm{z}$ test to determine statistical significance, the $\mathrm{z}$ score was found 17,069 . This result can be said to be statistically significant at the level of $p<0.001$. Thus, the application of RME results in a greater measure of the effect of students' mathematical abilities than conventional approaches.

Then 95 effect sizes were examined based on the characteristics of the study, namely the year of study, school level, the sample size of the experiment, source of publication, and the duration of the experiment. Table 5 below is a summary of the results of the analysis.

Table 5. Summary of Analysis Results

\begin{tabular}{|c|c|c|c|c|c|c|c|c|}
\hline \multirow[b]{2}{*}{$\begin{array}{c}\text { Study } \\
\text { Characteristics }\end{array}$} & \multirow[b]{2}{*}{ Group } & \multirow[b]{2}{*}{$\begin{array}{l}\text { Number } \\
\text { Studies }\end{array}$} & \multirow[b]{2}{*}{$\begin{array}{l}\text { Hedge's } \\
\mathrm{g}\end{array}$} & \multicolumn{2}{|c|}{$\begin{array}{c}\text { Test of null } \\
\text { (2-Tail) }\end{array}$} & \multicolumn{3}{|c|}{ Heterogeneity } \\
\hline & & & & $\begin{array}{c}\text { Z- } \\
\text { value }\end{array}$ & p & $\begin{array}{c}\text { Between- } \\
\text { Classes } \\
\text { Effect } \\
\text { (Qb) }\end{array}$ & df(Q) & $\mathbf{p}$ \\
\hline \multirow{2}{*}{ Year of Study } & $2010-2015$ & 54 & 1.099 & 27.366 & 0.000 & \multirow{2}{*}{0.287} & & \\
\hline & 2016-2019 & 41 & 1.025 & 22.894 & 0.000 & & 1 & 0.592 \\
\hline School Level & PS & 44 & 1.069 & 24.738 & 0.000 & 4.309 & & \\
\hline
\end{tabular}




\begin{tabular}{|c|c|c|c|c|c|c|c|c|}
\hline \multirow{3}{*}{$\begin{array}{c}\text { Study } \\
\text { Characteristics }\end{array}$} & \multirow[b]{2}{*}{ Group } & \multirow[b]{2}{*}{$\begin{array}{l}\text { Number } \\
\text { Studies }\end{array}$} & \multirow[b]{2}{*}{$\begin{array}{l}\text { Hedge's } \\
\text { g }\end{array}$} & \multicolumn{2}{|c|}{$\begin{array}{c}\text { Test of null } \\
\text { (2-Tail) }\end{array}$} & \multicolumn{3}{|c|}{ Heterogeneity } \\
\hline & & & & $\begin{array}{c}\text { Z- } \\
\text { value }\end{array}$ & $\mathbf{p}$ & $\begin{array}{c}\text { Between- } \\
\text { Classes } \\
\text { Effect } \\
\text { (Qb) }\end{array}$ & $\operatorname{df}(Q)$ & $\mathbf{p}$ \\
\hline & $\mathrm{JHS}$ & 47 & 0.969 & 24.736 & 0.000 & & 2 & 0.116 \\
\hline & SHS \& VHS & 4 & 0.848 & 6.050 & 0.000 & & & \\
\hline \multirow{2}{*}{ Sample Size } & 30 or less & 53 & 1.104 & 26.196 & 0.000 & \multirow{2}{*}{9.649} & & \\
\hline & 31 or over & 42 & 0.928 & 24.417 & 0.000 & & 1 & 0,000 \\
\hline \multirow{2}{*}{$\begin{array}{l}\text { Source } \\
\text { Publication }\end{array}$} & Journal & 81 & 1.004 & 32.898 & 0.000 & \multirow{2}{*}{0.030} & & \\
\hline & Proceedings & 14 & 1.020 & 13.802 & 0.000 & & 1 & 0.645 \\
\hline \multirow{3}{*}{$\begin{array}{l}\text { Duration of the } \\
\text { experiment }\end{array}$} & 0-7 hours & 38 & 1.268 & 25.977 & 0.000 & \multirow{3}{*}{65.563} & \multirow{3}{*}{2} & \multirow{3}{*}{0.000} \\
\hline & 8-14 hours & 18 & 0.987 & 10.313 & 0.000 & & & \\
\hline & $\begin{array}{l}15 \text { hours or } \\
\text { more }\end{array}$ & 39 & 0.634 & 23.604 & 0.000 & & & \\
\hline
\end{tabular}

According to the random-effects model, the effect size of the study is 1,104 , indicating that learning that applies RME has a strong influence on students' mathematical abilities when compared to conventional learning. The effect size of 1,104 indicates that the average student exposed to RME exceeds the mathematical ability of $79 \%$ of students in the conventional class who are initially equivalent. This finding can also be interpreted that students shift from the 50th percentile to the 84th percentile in mathematical abilities when RME is applied. Besides the effect size of 1,104, if you are confirming with the interpretation table (Coe, 2002), it can be interpreted that the average person is ranked 13th in the experimental group, equivalent to those ranked 4 th in the control group.

This finding does not differ greatly with research (Prasetiyo et al., 2014; Turgut \& Temur, 2017), which found an effect size of 0.900 and 0.840 when they each synthesized 22 and 47 studies comparing conventional and cooperative learning models to students' mathematical abilities. Similar results were reported by (Asror, 2016). In his research found an effect size of 0.94 for the effectiveness of the Problem Based Learning model compared to conventional learning on students' mathematical abilities. Similar results were also shown by (Tumangkeng, Yusmin, \& Hartoyo, 2018), who found the effect size of 0.95 when they synthesized 31 studies comparing learning using conventional mathematics with media on students' mathematical abilities. This finding shows a new fact that the application of RME produces a larger effect size than conventional approaches, cooperative approaches, and Problem Based Learning as well as learning using media.

This meta-analysis detected significant differences in effect sizes based on study characteristics. When Table 5 was examined, it appeared that the $\mathrm{Z}$ scores for all study characteristics were found to be greater than the $\mathrm{Z}$ table at the level of $\mathrm{p}<0.001$. This means that the application of RME is more effective than conventional learning in terms of study characteristics. Characteristics based on the year of the study found that studies conducted from 2010 to 2015 had an effect size of 1,099 (high level) almost the same as the effect size in studies between 2016 and 2019 of 1,025 (very high level). The statistical value of Qb obtained as a result of the homogeneity test was calculated as 0.287 . This value is smaller than the value of 3,841 at a $95 \%$ confidence interval from the 0.05 significance level. This means that there are no significant differences between the study groups. This finding is consistent with other studies conducted by (Bayir \& Bozkurt, 2018). The researchers found the effect sizes of studies conducted from 2005 to 2010 did not differ greatly from the effect sizes of studies conducted from 2011 to 2016. 
According to the results of the analysis given in Table 5, the effect size in studies conducted in primary schools (PS) of 1,069 (high level) does not differ greatly from the effect sizes in studies conducted in junior high schools (JHS) of 0.969 (high levels ). Both are not much different from the effect size in studies conducted in high school and vocational schools (SHS \& VHS), which is equal to 0.848 (high level). The Qb statistical value obtained as a result of the homogeneity test was calculated as 4,309 . Because this value is smaller than the value of 5.99 at the $95 \%$ confidence level, the significance level is 0.05 , so it can be said that there is no significant difference in the effect sizes between groups according to the school level. This result is different from the findings of research conducted by (Asror, 2016) that the application of problem-based learning models as part of constructivism-based learning models is more effective in junior high than in high school.

Judging from the sample size summary of the results in Table $\mathbf{5}$ shows the size of the effect on studies conducted with a range of 1-30 students amounting to 1,104 (very high level) greater than the size of the effects on studies conducted with a range of 31 or more students amounting to 0.928 (level high). The statistical value of $\mathrm{Qb}$ obtained as a result of the homogeneity test was calculated as 9,649. Because this value is greater than the value of 3,841 at the $95 \%$ confidence level, the significance level is 0.05 , so it can be said that there is a significant difference in effect sizes between groups according to sample size. This result is very different from the findings (Bayir \& Bozkurt, 2018). Based on the sample size, the researchers found that small samples have smaller effect sizes than large samples. This difference in results is another issue that can be further investigated.

Based on publication sources, it was found that the effect size on studies published in national and international journals was 1,004 (high level); the size of the effect on studies published on proceedings was 1,020 (high level). The statistical value of $Q$ obtained as a result of the homogeneity test was calculated as 0.030 . Because this value is smaller than the value of 3,841 at the $95 \%$ confidence level, the significance level is 0.05 , so there is no significant difference in the effect sizes between groups according to published sources.

Judging from the duration of the treatment it was found that the effect size in studies conducted between 0-7 hours was 1,268 (very high level); effect size in studies conducted between 8-14 hours was 0.987 (high level); and the size of the effect on studies conducted between 15 hours or more (moderate level). The statistical value of Q obtained as a result of the homogeneity test is 65,563 . Because this value is greater than the 5.99 value at the $95 \%$ confidence level, the significance level is 0.05 , so there is a significant difference in the effect sizes between groups according to published sources.

\section{CONCLUSION AND SUGGESTIONS}

This meta-analysis was carried out to investigate the effectiveness of the application of RME to students' mathematical abilities. According to the random-effects model, with a 95\% confidence interval, the effect size was calculated at 1,104 with a standard error of 0.065 . This shows that the application of RME results in a greater effect on students' mathematical ability than conventional approaches. Judging from the characteristics of the study, it produced a significant difference in terms of sample size and the duration of the experiment. Thus the application of RME in Indonesia is very effective in improving students' mathematical abilities by considering the sample size and the duration of the experiment. This finding also shows that RME can be applied at various levels of education.

Although this analysis shows that the application of RME has a very high effect on students' mathematical abilities, this finding is only based on studies that allow the calculation of effect sizes. There are still many similar studies that have not been analyzed because the statistical information needed is inadequate. This research has not yet reached other characteristics such as research sites, types of mathematical abilities, learning materials, 
and others. As a result, the conclusions in this study do not necessarily reflect the overall effectiveness of the RME. Therefore in the future, researchers are advised to conduct research by analyzing more studies so that they can reach the variables needed.

\section{ACKNOWLEDGMENT}

The authors thank primary study researchers for sending the necessary statistical information. The same thanks to the Santu Paulus Ruteng Foundation, who funded this research.

\section{REFERENCES}

Artawa, R., Wyn, ign i, \& Suwatra. (2012). Pengaruh Model Pembelajaran Kooperatif Tipe Make aMatch Terhadap Prestasi Belajar Matematika Siswa Kelas V Sd di gugus 1 kecamatan selat. Mimbar PGSD, (1), 1-10.

Asror, A. H. (2016). Meta-Analisis : Problem Based Learning. Unnes, 508-513.

Bayir, O. G., \& Bozkurt, M. (2018). Effectiveness of Cooperative Learning Approaches Used in the Course of Social Studies in Turkey: A Meta-Analysis Study. Online Submission, 4(10), 171-192. https://doi.org/10.5281/zenodo.1313863

Borenstein, M., \& Hedges, L. V. (2009). Introduction to Meta-Analysis (first). United Kingdim: WILEY A John Wiley and Sons, Ltd, Publication.

Borenstein, M., Hedges, L., \& Rothstein, H. (2007). Meta-Analysis Fixed effect vs . random effects. Test, 162. https://doi.org/10.1002/9780470743386

Clements, M. A., Keitel, C., Bishop, A. J., Kilpatrick, J., \& Leung, F. K. S. (2013). From the few to the many: historical perspectives on who should learn mathematics. In Third International Handbook of Mathematics Education. https://doi.org/10.1007/978-1-4614-4684-2

Cleophas, T. J., \& Zwinderman, A. H. (2017). Modern Meta-Analysis. In Modern Meta-Analysis. https://doi.org/10.1007/978-3-319-55895-0

Coe, R. (2002). It' s the Effect Size , Stupid: What effect size is and it is important. Educational Research, (September), 1-18.

Cohen, J. (1988). Statistical power analysis for the behavioral sciences. In Department of Psychology, New York University (Vol. 111). https://doi.org/10.1192/bjp.111.479.1009-a

Demir, S., \& Başol, G. (2014). Effectiveness of computer-assisted mathematics education (CAME) over academic achievement: A meta-analysis study. Kuram ve Uygulamada Egitim Bilimleri, 14(5), 2026-2035. https://doi.org/10.12738/estp.2014.5.2311

Dwi Yanti, Wahyu Widada, \& Zamzaili. (2018). Pengaruh Linier Kovariat Komunikasi Matematis Peserta Didik Terhadap Rerata Kemampuan Akhir Peserta Didik Dengan Pendekatan Pembelajaran Matematika Realistik Berorientasi Etnomatematika Bengkulu. Jurnal Pendidikan Matematika Raflesia, 3(2), 82-93. https://doi.org/https://doi.org/10.31186/jpmr.v3i2.6289

Ekowati, C. K., \& Nenohai, J. M. H. (2016). The Development of Thematic Mathematics Book Based on Environment with a Realistic Approach to Implant the Attitude of Caring about Environment at Students of Elementary School Grade One in Kupang. International Journal of Higher Education, 6(1), 112. https://doi.org/10.5430/ijhe.v6n1p112

Ellis, P. D. (2010). The Essential Guide to Effect Sizes. The Essential Guide to Effect Sizes. https://doi.org/10.1017/cbo9780511761676

Fauzan, A., Slettenhaar, D., \& Plomp, T. (2002). Traditional Mathematics Education vs . Realistic Mathematics Education: Hoping for Changes. Proceedings of the 3rd International Mathematics Education and Society Conference, 1-4. Copenhagen: Centre for Research in Learning Mathematics.

GLASS, G. V. (1976). Primary, Secondary, and Meta-Analysis of Research. Educational Researcher, 5(10), 3-8. https://doi.org/10.3102/0013189x005010003

Hasibuan, A. M., Saragih, S., \& Amry, Z. (2019). Development of Learning Materials Based on Realistic Mathematics Education to Improve Problem Solving Ability and Student Learning Independence. International Electronic Journal of Mathematics Education, 14(1), 243-252. https://doi.org/10.29333/iejme/4000

Hasratuddin, H. (2010). Meningkatkan Kemampuan Berpikir Kritis Siswa Smp Melalui Pendekatan 
Matematika Realistik. Jurnal Pendidikan Matematika, 4(2), 19-33. https://doi.org/10.22342/jpm.4.2.317.

Hedges, L. V, \& Olkin, I. (1985). Statistical Methods in Meta-Analysis. Journal of Educational Statistics, (July). https://doi.org/10.2307/1164953

Husniyah, N., Sulistiani, I. R., \& Mustafida, F. (2019). Pengaruh Model Pembelajaran Matematika Realistik Terhadap Pemahaman Konsep Siswa Kelas IV MI Hidayatul Mubtadi'in Tasikmadu Malang. Jurnal Pendidikan Madrasah Ibtidaiyah, 1(3), 83-96.

Nursiddik, I., Noto, M. S., \& Hartono, W. (2017). Pengaruh Pembelajaran Matematika Realistik Terhadap Kemampuan Pemahaman Matematis dan Keyakinan Diri Siswa SMP. UNION: Jurnal Ilmiah Pendidikan Matematika, 5(2), 151-160. https://doi.org/10.30738/.v5i2.1085

Palinussa, A. L. (2013). Students' critical mathematical thinking skills and character: IndoMS.J.M.E, 4(1), 75-94.

Panhuizen, M. V. d H., \& Drijvers, P. (2014). Ability Grouping in Mathematics Classrooms. Encyclopedia of Mathematics Education, 521-534. https://doi.org/10.1007/978-94-007-4978-8

Park, S., \& Hong, S. (2016). The empirical review of meta-analysis published in Korea. Asia Pacific Education Review, 17(2), 313-324. https://doi.org/10.1007/s12564-016-9433-x

Pigott, T. D. (2012). Advances in Meta-Analysis. Chicago, IL, USA: Springer is part of Springer Science+Business Media.

Prasetiyo, A. Y., Yusmin, E., \& Hartoyo, A. (2014). Meta-analisis pengaruh cooperative learning terhadap peningkatan hasil belajar matematika siswa. Jurnal Untan, 1(1), 1-11.

Putri, F. M. (2011). Pengaruh Pembelajaran Matematika Realistik Terhadap Kemampuan Penalaran Matematis Siswa SMP. Jurnal Edumatica, 03(01), 19-26.

Richard, J., Light, R., \& Pillemer, D. B. (1984). Summing up. Harvard University Press.

Rohmah, N., Caswita, \& Widyastuti. (2014). Penerapan Pendekatan Realistic Mathematics Education untuk Meningkatkan Kemampuan Pemecahan Masalah Matematis Siswa. Jurnal Pendidikan Matematika Unila, 2(6).

Rohman, H. M. H., \& Sugiman. (2015). The Influence of Realistic Mathematics Education Implementation In Cooperative Settings Types Think Pair Share (TPS) Against The Ability of Junior High School Student's Mathematical Literacy. Jurnal Pendidikan Matematika, 1-9.

Schwarzer, G., Carpenter, J. R., \& Rücker, G. (2015). Small-Study Effects in Meta-Analysis. https://doi.org/10.1007/978-3-319-21416-0_5

Shelby, L. B., \& Vaske, J. (2008). Understanding meta-analysis: A review of the methodological literature. Leisure Sciences, 30(2), 96-110. https://doi.org/10.1080/01490400701881366

Thalheimer, W., \& Cook, S. (2002). Effect_Sizes_pdf5.pdf. Work Learning Recearch, (August), 1-9.

Tumangkeng, Y. W., Yusmin, E., \& Hartoyo, A. (2018). Meta Analysis Pengaruh Media Pembelajaran Terhadap Hasil Belajar Matematika Siswa. Jurnal Pendidikan Dan Pembelajaran Katulistiwa, 10(2), $1-15$.

Turgut, İ. G., \& Turgut, S. (2018). The effects of visualization on mathematics achievement in reference to thesis studies conducted in Turkey: A meta-analysis. Universal Journal of Educational Research, 6(5), 1094-1106. https://doi.org/10.13189/ujer.2018.060531

Turgut, S., \& Dogan Temur, Ö. (2017). The effect of game-assisted mathematics education on academic achievement in Turkey: A meta-analysis study. International Electronic Journal of Elementary Education, 10(2), 195-206. https://doi.org/10.26822/iejee.2017236115

Turmudi. (2012). Teachers ' Perception Toward Mathematics Teaching Innovation in Indonesian Junior High School : An Exploratory Factor Analysis. Journal of Mathematics Education, 5(1), $97-$ 120.

WILLETT, J. B. (1993). The visual presentation and interpretation of meta-analyses. The Handbook of Research Synthesis, 439.

Yunisha, R., Prahmana, R. C. I., \& Sukmawati, K. I. (2016). Pengaruh Pendekatan Pendidikan Matematika Realistik terhadap Kemampuan Komunikasi Matematis Siswa Kelas VII SMP. Jurnal Elemen, 2(2), 136. https://doi.org/10.29408/jel.v2i2.284

Zulkardi. (2002). D Eveloping a L Earning E Nvironment on $R$ Ealistic $M$ Athematics $E$ Ducation. University of Twente. 